\title{
A TELEPÜLÉSTERVEZÉS ÚJ IRÁNYAI MAGYARORSZÁGON, EGY TELEPÜLÉS - EGY TERV
}

\author{
Kolossa József, Gombos Márk, \\ ábrák: Kállai Kata
}

\author{
Miniszterelnökség, Építészeti és Építésügyi Helyettes Államtitkárság, Településtervezési és \\ Területrendezési Főosztály, 1054 Budapest, Báthory u. 12. \\ e-mail: jozsef.kolossa@me.gov.hu,mark.gombos@me.gov.hu
}

\section{A településtervezés jelenlegi helyzete}

\section{A hatályos jogszabályi háttér}

A Magyarország helyi önkormányzatairól szóló 2011. évi CLXXXIX. törvény (a továbbiakban: Mötv.) értelmében a településfejlesztés és a településrendezés a helyi közügyek, valamint a helyben biztosítható közfeladatok körében ellátandó kötelező önkormányzati feladatok egyike. A településrendezés és településfejlesztés alapvető szabályait az épített környezet alakításáról és védelméről szóló 1997. évi LXXVIII. törvény (a továbbiakban: Étv.) rögzíti.

A településrendezés és településfejlesztés az önkormányzati törvényben felsorolt, szinte valamennyi helyi önkormányzati feladattal összefüggésben lévő, tartalmában összetett, emellett sokszereplős és általában időigényes tevékenység.

A településfejlesztés és a településrendezés célja a lakosság életminőségének és a település versenyképességének javítása érdekében a fenntartható fejlődést szolgáló településszerkezet és a jó minőségű környezet kialakítása, a közérdek érvényesítése az országos, a térségi, a települési és a jogos magánérdekek összhangjának biztosításával, a természeti, táji és építészeti értékek gyarapítása és védelme, valamint az erőforrások kíméletes és környezetbarát hasznosításának elősegítése.

A településfejlesztés és a településrendezés legfontosabb feladata, hogy biztosítja a helyét a település közigazgatási területén megvalósuló (állami, önkormányzati, vállalati, lakossági...) beruházásoknak.

Az Étv. alapján a településfejlesztés feladata a településen élők számára a települési életés környezetminőség javítása, a környezetbiztonság erősítése, a települési erőforrásokra építő, az erőforrások fenntarthatóságát biztosító, hosszú és rövid távú fejlesztési irányok, célok és az azok elérését biztosító programok és eszközök meghatározása. A településfejlesztés meghatározza a települések céljait, amelyek megvalósításának az eszköze a településrendezési tervek. Az önkormányzatok a településfejlesztési szándékaikat a hosszú távra készülő településfejlesztési koncepcióban és a közép/rövidtávra készülő integrált településfejlesztési stratégiában rögzítik.

A településrendezés feladata, hogy a település területének, telkeinek felhasználására és az építés helyi rendjére vonatkozó szabályok kialakításával

- meghatározza a település összehangolt, rendezett fejlödésének térbeli-fizikai kereteit,

- a település adottságait és lehetőségeit hatékonyan kihasználva elösegítse annak müködőképességét a környezeti ártalmak legkisebbre való csökkentése mellett,

- biztosítsa a település müködéséhez szükséges infrastruktúra-hálózatot, valamint

- biztosítsa a település, településrészek megörzésre érdemes jellegzetes, értékes szerkezetének, beépítésének, építészeti, természeti és tájképi arculatának védelmét.

A területhasználat meghatározása a települési önkormányzatok kizárólagos joga, amely a településszerkezeti tervben kerül meghatározásra. A településszerkezeti tervvel és a 
településképi rendelettel összhangban készülő helyi építési szabályzat és melléklete a szabályozási terv a településképi követelmények kivételével, megállapítja a helyi építési követelményeket, jogokat és kötelezettségeket.

Új intézményrendszerként, a településrendezési követelményekkel összhangban került bevezetésre 2016-ban a településkép-védelmi követelmények meghatározása. A településkép védelméről szóló törvény alapján a települési önkormányzatok településképi arculati kézikönyvet készítenek és településképi rendeletet fogadnak el, amelyek célja a helyi településképi követelmények a helyi közösségek által is elfogadott, közérthető nyelven, szemléletformáló módon történő megfogalmazása.

A hatályos jogszabályok szerinti települési tervek egy összetett tervrendszert alkotnak (1. ábra). Ezen tervek elkészítése az önkormányzatok számára jelentős feladatot, anyagi terhet jelentenek, elkészítésük hosszadalmas. A laikusok számára sok esetben átláthatatlan tervrendszer nem biztosít egyértelmü, közérthető szabályrendszert, amely visszaéléseket, jogbizonytalanságot okozhat.

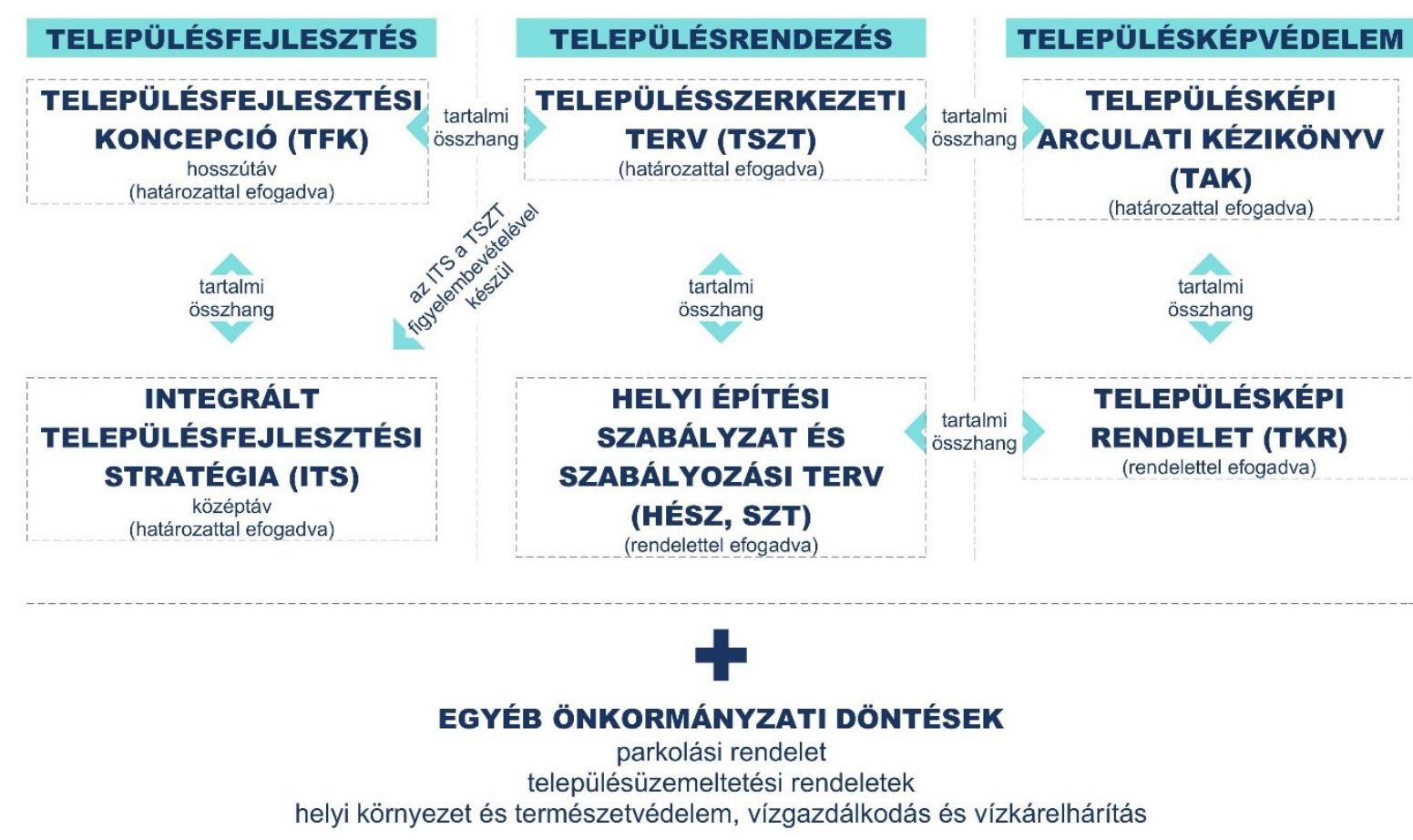

1. ábra: A hatályos jogszabályok szerinti települési tervek és tartalmi összefüggéseik.

\section{Települési zöldfelületek szabályozása, klímavédelem}

A zöldfelületek jelentős szerepet játszanak a települési klímavédelemben, elsősorban a szélsőségek kiegyenlítésében (lezúduló csapadékvíz, hőhullámok), ami Magyarországon a legnagyobb klímakockázati tényező. Az Étv. egyértelmüen az építésügy hatáskörébe sorolja a települési zöldfelületekkel kapcsolatos feladatokat. A zöldfelületek és az épített környezet összhangja egy település müködésének és megjelenésének egyaránt fontos szempontja. A közterületi zöldfelületek, zöldterületek kialakítása ugyanúgy magukon viselik a korszellem sajátságait, mint az épületek. Helyes kialakításuk tehát számottevően hozzájárul a településkép, településkarakter erősítéséhez.

A zöldfelületek a településszerkezetben sajátos rendszert képeznek. Fontos, hogy e szerkezet arányosan legyen elosztva, mindenki egyenlő mértékben férjen hozzá e területekhez, illetve azok egyenletesen fejtsék ki hatásukat. A települések tervezése során ezért e hálózat teljességére kell törekedni a térbeli eloszlás és a minőség terén egyaránt. 
A zöldfelületekre vonatkozó szabályozási környezet nem teljes, mert hiányzik településképi, településrendezési, településfejlesztési és tájképi szabályozás összhangja. A hiányos szabályozás környezet miatt felmerülö legjelentősebb problémák:

- A zöldfelület gazdálkodás, fenntartás és üzemeltetés településtervezést érintő szabályozása hiányos, az önkormányzati feladatellátás nem egyértelmü.

- A zöldfelületek szabályozása több ágazatot érint, ugyanakkor alapvető kompetenciakérdések nem tisztázottak.

- A fakivágás és a fapótlás keretszabályozása hiányos.

- Az ingatlanvagyon kataszterben a fogalmi és a strukturális hiányosságok miatt a zöldfelületi vagyon pontosan nem rögzíthető és tartható nyilván, továbbá értéke nem állapítható meg.

- A településkép - védelmi és a településrendezési szabályozás zöldfelületek minőségi szabályozására vonatkozó elöírásai hiányosak.

- A környezeti vizsgálat tervezésre gyakorolt hatása nem igazolt. A folyamat költséges, időigényes, jellemzően egy adott beruházás vagy településrendezési eszköz módosítás igazolására készülő dokumentum, jogkövetkezmények nélkül záródó eljárással.

\section{3. Önkormányzatok településtervezési kihívásai}

A településtervezés feladata, hogy kiszámítható és egyértelmü követelményekkel, jogi eszközökkel választ adjon a települések természeti, épített és táji környezetének problémáira. $\mathrm{Az}$ elmúlt években több felmérés is készült, amelyek tapasztalatai alapján azonosíthatók a településeket érő kihívások. A Belügyminisztérium koordinálásával megvalósuló KÖFOP2.3.4-VEKOP-15-2016-00002 azonositószámú, „Önkormányzati fejlesztések figyelemmel kisérése II." (ÖFFK II.) elnevezésü projekt az önkormányzatok problémáit három szempont (online képesség, lakossági bevonás, önkormányzati együttmüködések) szerint csoportosította. Összegezve megállapítható, hogy

- az önkormányzatok digitális infrastruktúra hálózata, a digitális képzettsége igen eltérö, a kisebb települések jelentős hátrányban vannak,

- a kistelepülések jelentős részén a digitális, online kommunikáció kevésbé preferált, ez ebben rejlő lehetőségeket nem képesek kihasználni,

- sok önkormányzat esetében a döntés elökészítésbe a közösségi bevonás továbbra sem kedvelt és elterjedt módszer, így a társadalmi elégedettség és a kormányzás minősége nem fejlődik pozitív irányba,

- a közigazgatási ügymenet és eljárások (köztük a településtervezés is) bonyolult jogszabályok által szabályozottak, a lakosság által nehezen érthetők, a jogi szakkifejezések miatt a szabályozás a laikus számára nem átlátható,

- az önkormányzatok közötti együttmüködések száma alacsony, a meglévő együttmüködések korlátozottan müködőképesek.

A 2021-2027 közötti időszakra vonatkozó európai uniós kohéziós források felhasználásának tervezése kapcsán a Miniszterelnökség Építészeti és Építésügyi Helyettes Államtitkársága kérdőívek segítségével térképezte fel, hogy a települési önkormányzatok milyen irányokat képzelnek el a településük fejlesztése terén a következő 10 évben. Ezen fejlesztési szándékokból megállapíthatóvá váltak azok a területek, amelyek fejlesztési igénye kimagasló. A kérdőívek alapján az alapvető fejlesztési irányok az alábbiak szerint azonosithatók:

- Települési környezet fejlesztése és védelme: települési zöldfelületek és barnamezős területek fejlesztése, településkép általános fejlesztése, közmühálózatok fejlesztése, a csapadékvíz okozta problémák megoldása, vízvisszatartás és hasznosítás megoldása, a megújuló energiák hasznosításának növelése, a közintézmények energetikai 
korszerüsítése, a hulladékgazdálkodás fejlesztése, a klímavédelemmel kapcsolatos problémák kezelése (klímastratégia kidolgozása, levegőtisztaság, hőhullámok elleni védekezés, stb.).

- Közlekedési infrastruktúra fejlesztése: a belterületi, önkormányzati utak korszerüsítése, a települések térségi kapcsolatainak erősitése érdekében a közutak fejlesztése, a közösségi közlekedés fejlesztése, forgalomcsillapítás, parkolók kiépítése.

- Gazdaságfejlesztés: turizmus és idegenforgalom fejlesztése, szálláskapacitás növelése, új iparterületek kijelölése.

- Intézmények és szolgáltatások fejlesztése: sportlétesítmények kiépitése és fejlesztése, közszolgáltatások infrastruktúrájának fejlesztése, közintézmények fejlesztése.

Megállapítható, hogy az egymással szoros kölcsönhatásban lévő önkormányzati kihívások kezelése és a tervezett beavatkozások megvalósítása komplex tervezést igényel. Fontos cél, hogy az önkormányzatok olyan - a lakosság által is támogatott - terveket készítsenek, melyek közérthető és átlátható módon rendszerbe foglalják az önkormányzat településfejlesztési szándékait, egyúttal meghatározzák a település összehangolt, rendezett fejlődésének térbelifizikai, településképi kereteit, tekintettel a táji, természeti és ökológiai adottságokra, választ adva a klímaváltozás kihívásaira.

\section{A településtervezés új szabályozása - „egy település egy terv”}

A jelenlegi 6 külön terv és önkormányzati döntés helyett (településfejlesztési koncepció, integrált településfejlesztési stratégia, településszerkezeti terv, helyi építési szabályzat településképi arculati kézikönyv és településképi rendelet) az új koncepció egy egységes Település terv elkészítésére tesz javaslatot, amely különösen a kistelepülések számára jelent adminisztratív tehercsökkentést.

A Település terv a jelenlegi tervstruktúra átdolgozásával, a legszükségesebb elemek megtartása mellett és új hiánypótló tartalmi elemek bevezetésével az alábbi kötelező tartalommal készülne.

\section{I. tervrész: Településtervezési program:}

Az új szabályozás értelmében az önkormányzat a Település terv (2. ábra) I. tervrészeként elöször Településtervezési Programot készít. A Településtervezési Program része a Megalapozó vizsgálat, Helyzetelemzés és helyzetértékelés, amely a teljes Település terv megalapozását szolgálja. A Megalapozó vizsgálat egy olyan szöveges és rajzi adatbázis, amely rögzíti azokat a kiindulási adatokat, trendeket és folyamatokat, amelyek új koncepcióismerete nélkülözhetetlen a települések közép és hosszú távú fejlesztési irányainak meghatározásához.

A Településtervezési program feladata, hogy az önkormányzatok rögzítsék a jövőképüket, és ezen jövőkép elérését szolgáló célokat. A Településtervezési program a jelenlegi tervstruktúrához képest jelentősen egyszerüsíti és csökkenti az önkormányzatok településtervezési feladatait. A Településtervezési program a települési önkormányzat aktív részvételével készül, és hiánypótló módon, mintegy megrendelésként rögzíti azokat a beavatkozási pontokat, amelyeket a Település tervnek mindenképpen kezelnie kell. A Településtervezési program szöveges és közérthető rajzi munkarészeket egyaránt tartalmazó tervi rész, amely önkormányzati határozattal kerül elfogadásra. 


\section{TELEPÜLÉS TERV}

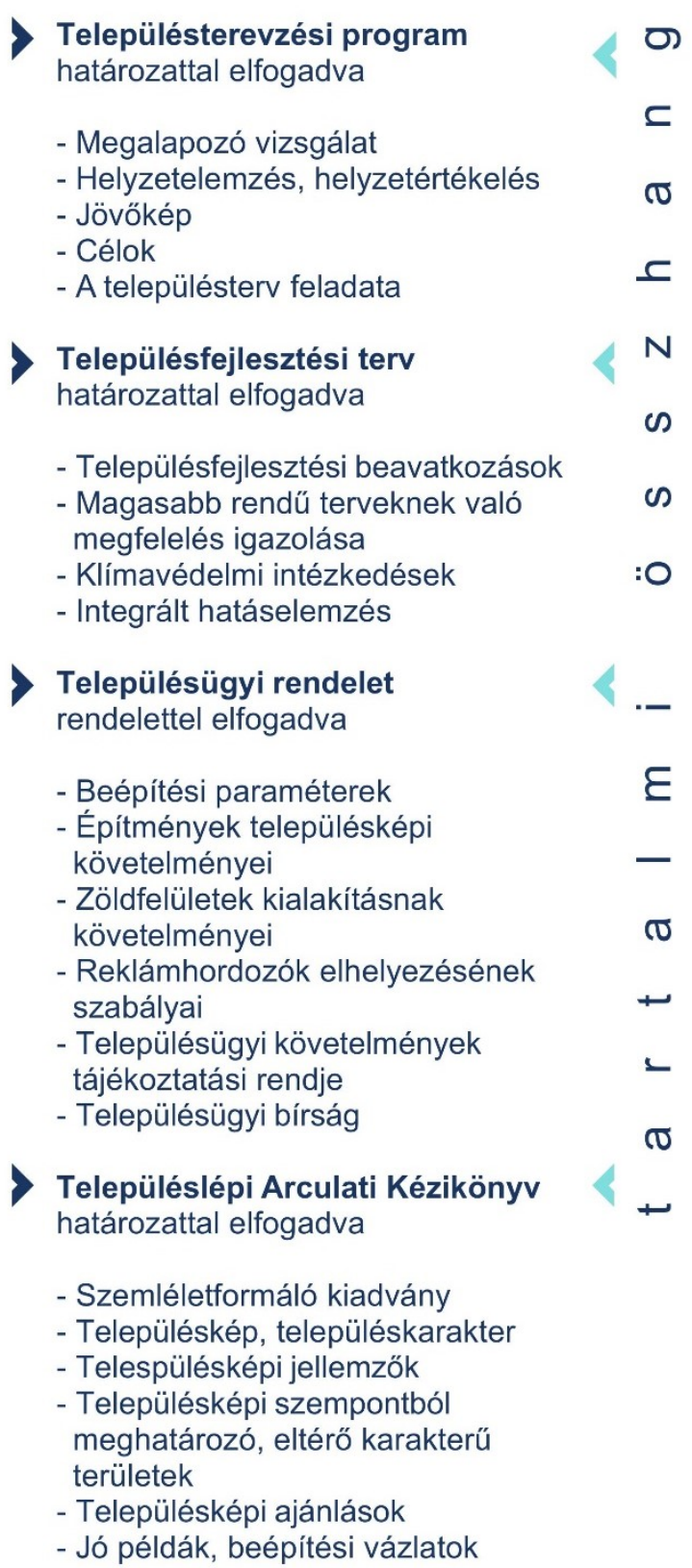

2. ábra: A Település terv elemei és tartalmi összefüggései

\section{II. tervrész: Településfejlesztési terv}

A Településtervezési program figyelembevételével készül az önkormányzati határozattal elfogadásra kerülő Településfejlesztési terv. A Településfejlesztési terv, szöveges és rajzi (térképi) munkarészeket is tartalmazó tervi rész.

A Településfejlesztési terv célja, hogy a település közigazgatási határán belül meghatározásra kerüljenek a település jövőképének és céljainak elérését biztosító fejlesztések, beavatkozások és intézkedések, a tervszerű és fenntartható területfelhasználási rendszer és az egyes területfelhasználási egységek követelményei, müszaki infrastruktúra hálózatok elemei, településszerkezeti jelentőségü elemek, a védelmek és korlátozások, a táj és természetvédelemi elemek, a zöldfelületi rendszer elemei és a müvi értékvédelem egyes elemei. A Településfejlesztési terv legfontosabb feladata, hogy a területfelhasználási 
rendszerben biztosítsa a tervezett fejlesztések térbeli és fizikai kereteit, valamint az ütemezett területfelhasználással egyértelmủek és közérthetőek legyen az önkormányzat távlati fejlesztési szándékai.

A Településfejlesztési tervben rögzítésre kerülnek a magasabb rendü tervekben szereplő országos, térségi és megyei érdekü fejlesztések és azok helybiztosítása, továbbá igazolásra kerül a magasabb rendủ terveknek való megfelelés.

A Településfejlesztési tervben az Önkormányzatoknak hiánypótló módon klímavédelmi és a klímaváltozás káros hatásait csökkentő intézkedéseket is rögzíteniük kell, összhangban Magyarország klímastratégiájával.

A Településfejlesztési terv az Integrált hatáselemzés bevezetésével jelentősen gyorsítja és egyszerüsíti a Település terv elfogadását, így az érintett beruházások megvalósítását is. Az új koncepció értelmében megszünik önálló dokumentumként a települési örökségvédelmi hatástanulmány, melynek vizsgálati része beépül a megalapozó vizsgálatba, valamint a hatáselemzés része a Településfejlesztési tervbe, továbbá megszünik önálló dokumentumként a településrendezési tervek hatásaira vonatkozó környezeti értékelés, és beépül a Településfejlesztési terv Integrált hatáselemzés fejezetébe. Ezen hatásvizsgálatok így nem válnak el a fó dokumentumtól, a véleményezésük és elfogadásuk egy eljárásban történhet, jelentősen egyszerüsítve és gyorsítva a tervezési folyamatot.

\section{III. tervrész: Településügyi rendelet}

A Település terv normatív rendelkezéseit a Településügyi rendeletet tartalmazza, a helyi építési szabályok és a településképi követelmények meghatározásával. A Településügyi rendelet a természetes és jogi személyek részére állapít meg kötelezettségeket (egyesítve és egyszerüsítve többek között a jelenlegi helyi építési szabályzatot és településképi rendeletet, a zöldfelületi szabályokat, a parkolási szabályok elöírásait).

A településügyi rendelet tekintetében az új koncepció jelentős egyszerüsítést vezet be a kistelepülések feladatellátása kapcsán, egyrészt a beépítési szabályok tekintetében meghatározásra kerül az a kötelező szabályozási kör, amelyröl valamennyi településnek rendelkeznie kell, míg a többi kérdéskörben, ha a jogszabály másként nem rendelkezik, az országos szabályok (OTÉK) automatikusan érvényesülnek. A Településügyi rendelet továbbra is - a jelenlegi tervrendszer helyi építési szabályzatához hasonlóan - az építési jogok és követelmények meghatározását szolgálja a beépítésre szánt és beépítésre nem szánt területek térbeli rendszerének és szabályozási követelményeinek meghatározásával, összhangban a Településfejlesztési terv területfelhasználási rendszerével.

A Településügyi rendelet mellékletét képzi a Szabályozási terv, amely a beépítésre szánt és beépítésre nem szánt területek térbeli rendszerét, az egyes területek szabályozását, a közterületek és nem közterületek viszonyát ábrázolja.

A polgármester a településrendezési és építési követelmények, valamint a településképi követelmények (azaz a település által rendeletben megállapított szabályok) betartását hatósági engedélyezés esetén, azt megelőzően településügyi véleményezésben, más, önkormányzati rendeletben rögzített esetekben településügyi bejelentéssel tudja érvényesíteni.

Az új koncepció szerinti új településtervezési szabályozással a területrendezési tervekkel való összhang megteremtése - amelyet a területrendezési és az építésügyi törvény jelenleg is hatályos állapota szerint a 2021. év végéig kell elérni - már az új szabályok szerint valósulhat meg. Azon települések számára, amelyek már megkezdték a még hatályos szabályok szerint a területrendezési tervekkel való összhang megteremtését - az elkészült megalapozó, alátámasztó részek felhasználásával - biztosított lesz az áttérés az új szabályrendszerre. 
IV. tervrész: Településképi Arculati Kézikönyv

A Település terv részeként, de külön szemléletformáló dokumentumban, a településkép védelméröl szóló 2016. évi LXXIV. törvény rendelkezései alapján az Önkormányzatok elkészítik a Településképi Arculati Kézikönyveiket. A kézikönyv a Település terv Megalapozó vizsgálati, Helyzetelemző és Helyzetértékelő munkarésze alapján, a Településtervezési program és a Településfejlesztési terv figyelembevételével készül a Településügyi rendelet településképi szabályozásának alátámasztására.

A kézikönyv célja a jelenlegi jogszabályi követelmények szerint változatlan marad. A kézikönyv feladata továbbra is a településkép bemutatása, jó példák és ajánlások meghatározása.

A már elkészített és elfogadott kézikönyveket az önkormányzatoknak nem kell újra elkészíteniük, azok tartalma és felépítése megfelel az új tervrendszernek.

\section{Az új tervrendszer várható hatásai - egy település egy terv előnyei}

A településtervezés hatályos jogszabályi keretei egy igen merev, kötött és összetett szabályrendszert alkotnak, amelyek a jelenlegi gyorsan változó gazdasági környezetében jelentősen megnehezítik a településfejlesztést. A hatályos szabályozás a stagnáló, fogyó népességü kistelepülések településtervezési feladatait sem támogatja, a legtöbb település problémájára nem tud egyértelmü választ adni. Mindezek mellett a településrendezéssel és településfejlesztéssel kapcsolatos kötelező önkormányzati feladatok jelentős bürokratikus és anyagi terhet rónak a településekre.

A hatályos jogszabályokban rögzített követelmények nem adnak választ a klímaváltozás kihívásaira. A jelenleg hatályos településrendezési tervek a jelenlegi jogszabályi követelmények alapján nem, vagy csak korlátozottan kezelik a települési zöldfelületek fenntartásával és fejlesztésével kapcsolatos kérdéseket. Az új koncepció célja, hogy a települések határozzák meg azokat az intézkedéseket, amelyek mind a zöldfelületek fejlesztésére és fenntartására, mind a klímakockázatokra érdemi választ és megoldást adnak.

Az új településtervezési szabályozás jelentős segítséget biztosít mind a fejlődő, gazdasági erővel rendelkező, mind a stagnáló, fogyó népességü, gazdaságilag elmaradott települések számára.

Az EGY TELEPÜLÉS EGY TERV szabályozás eredményeként:

- csökkennek a települések településtervezés kapcsán ellátandó bürokratikus terhei,

- a kiemelt, közérdekü beruházások megvalósítása egyszerübb és gyorsabb lesz,

- a Település terv elkészítése gyorsabb, egyszerübb és olcsóbb lesz,

- a településtervezés és a Település terv átláthatóbb, könnyebben értelmezhető lesz, a lakosság számára is közérthető módon mutatja be a település fejlődésének irányait és a fejlesztési szándékait,

- az új eljárási szabályok alapján a Település terv módosítása, így az építési beruházások megvalósítása is gyorsabbá válik,

- a településtervezés szabályrendszere differenciált lesz, rögzítésre kerül a kötelezően elkészítendő minimum szabályozási tartalom, ugyanakkor a nagyobb, vagy fejlődő települések számára biztosított lesz a lehetőség egy komplexebb helyi szabályozás kialakítására,

- a Település tervek egységes tartalommal történő elkészítésével előáll az országos, térségi, megyei és települési tervek közötti összhang,

- a településtervezés teljesen digitális alapokra kerül,

- az új Település tervek elkészítésével átláthatóbb, kiszámíthatóbb helyi szabályozás jön létre,

- a Település tervek elkészítése tervezési alapot biztosít az EU programozási 
időszakhoz, így hatékonyabban felhasználhatók lesznek a rendelkezésre álló források.

Az Egy Település Egy Terv szabályozás átfogóan egyszerüsíti a településtervezést, az eljárások gyorsabbá és egyszerübbé válnak az építési beruházásokhoz kapcsolódó eseti szabályozási módosítások gyorsabban megvalósíthatók, így a beruházások költsége csökkenthetö.

Az új szemléletü, korszerü és digitális Település terv könnyen értelmezhető, közérthető tervrészekből áll, amely a hatályos tervekhez képest a laikus felhasználó számára könnyebben értelmezhető.

Az új Település tervek a magasabb rendủ országos tervekkel összhangban készülnek, kiszürve a jogbizonytalan helyzeteket.

\section{A KORSZERŰ TELEPÜLÉSTEREVZÉS MÉRŐSZÁMAI}

\begin{tabular}{|c|c|c|c|}
\hline & Jelenlegi állapot & 2022 - Egy Település Egy Terv & $\begin{array}{l}\text { jkkentés } \\
\text { mértéke }\end{array}$ \\
\hline tervek száma & $\begin{array}{l}6 \text { terv } \\
\text { + rajzi mellékletek }\end{array}$ & $\begin{array}{l}1 \text { terv } \\
+ \text { rajzi mellékletek }\end{array}$ & $70 \%$ \\
\hline költségek & $\begin{array}{l}\text { kistelepülés 6-10 M Ft } \\
\text { kisvárosok } 10-15 \mathrm{M} \mathrm{Ft} \\
\text { nagyvárosok } 15-25 \mathrm{M} \mathrm{Ft}\end{array}$ & $\begin{array}{l}\text { kistelepülés 3-6 M Ft } \\
\text { kisvárosok 6-8 M Ft } \\
\text { nagyvárosok 8-13 M Ft }\end{array}$ & $50 \%$ \\
\hline klímavédelem & nem érvényesül & $\begin{array}{l}\text { kiemelt prioritás } \\
\text { tervezési szempont }\end{array}$ & \\
\hline versenyképesség & mérsékelten támogatja & $\begin{array}{l}\text { tervezési szempont } \\
\text { kistelepülések } \\
\text { versenyképességének javítása }\end{array}$ & \\
\hline $\begin{array}{l}\text { kis települések } \\
\text { támogatása }\end{array}$ & $\begin{array}{l}\text { nem tesz különbséget a } \\
\text { kistelepülések és a } \\
\text { nagyvárosok között }\end{array}$ & $\begin{array}{l}\text { differenciált követelmények a } \\
\text { kistelepülések adottságaihoz } \\
\text { igazodva }\end{array}$ & \\
\hline tervek elkészülési ideje & általában: 6-8 hónap & $\begin{array}{l}\text { kiemelt fejlesztéseknél: 1-3 hét } \\
\text { általában: 2-3 hónap }\end{array}$ & $60 \%$ \\
\hline egyeztetési idő & 50 nap & 30 nap & $40 \%$ \\
\hline digitalizáció & $\begin{array}{l}\text { részben digitalizált } \\
\text { sok esetben papír alapú tervek }\end{array}$ & $\begin{array}{l}\text { teljes digitalizáció } \\
\text { azonnal, online hozzáférhető digitális tervek }\end{array}$ & \\
\hline $\begin{array}{r}\text { adatszolgáltatás jellege } \\
\text { és pontossága }\end{array}$ & $\begin{array}{l}\text { különböző állapotú, } \\
\text { pontatlan és késleltetett } \\
\text { feldolgozású adatok }\end{array}$ & $\begin{array}{l}\text { egységes } \\
\text { digitális } \\
\text { naprakész, dinamikus } \\
\text { azonnal hozzáférhető }\end{array}$ & \\
\hline egyeztetés felülete & $\begin{array}{l}\text { lassú papír és } \\
\text { postai alapú egyeztetés }\end{array}$ & $\begin{array}{l}\text { gyors, dinamikus, webes } \\
\text { egyeztető felület } \\
\text { digitális tervekkel }\end{array}$ & $80 \%$ \\
\hline $\begin{array}{r}\text { kompatibilitás országos } \\
\text { és megyei szinttel }\end{array}$ & $\begin{array}{l}\text { nehéz megfeleltethetöség } \\
\text { tervi szintek közötti } \\
\text { koherenciazavar }\end{array}$ & $\begin{array}{l}\text { egymással koherens tervek } \\
\text { azonos alaptérkép } \\
\text { jogbiztonság }\end{array}$ & \\
\hline $\begin{array}{l}\text { használhatóság / } \\
\text { felhasználói élmény }\end{array}$ & $\begin{array}{l}\text { nehezen értelmezhetö, } \\
\text { bonyolult tervek } \\
\text { bonyolult tervstruktúra } \\
\text { bonyolult jogesetek }\end{array}$ & $\begin{array}{l}1 \text { terv } \\
\text { könnyen értelmezhető és kezelhető } \\
\text { jogbiztonság }\end{array}$ & \\
\hline
\end{tabular}

